\title{
Concentrated Photovoltaics
}

\author{
Robert McConnell ${ }^{1}$ and Vasilis Fthenakis ${ }^{2,3}$ \\ ${ }^{1}$ Amonix Inc. \\ ${ }^{2}$ National Photovoltaic Environmental Research Center \\ Brookhaven National Laboratory and \\ ${ }^{3}$ Columbia University \\ USA
}

\section{Introduction}

Concentrating sunlight by using mirrors or lenses historically is associated with generating heat. Though often discredited since the Renaissance, there are Roman records that Archimedes used mirrors and the sun's energy to attack Roman ships by setting them on fire (Archimedes, 2011). At the turn of the $19^{\text {th }}$ century, several inventors and engineers used heat from solar concentrators to operate steam engines to pump water and, later, to generate electricity via rotating machinery (Backus, 2003). With the invention of modern photovoltaics, and in a quest to increase efficiencies and reduce costs, engineers in the 1970s demonstrated that concentrating sunlight and focusing the equivalent of hundreds of "suns" onto solar cells increases their efficiency (Backus, 2003). For example, 20.7\% efficient mono-c-Si cells, under AM1.5 spectral conditions, reach $26.5 \%$ efficiencies under 500 suns because the efficiency of a solar cell increases as the voltage- and fill factor of the cell rise. However, further increases in solar concentration require augmented cell package designs to collect the increased electrical current and dissipate additional waste heat. Otherwise there will be a decline in efficiency as shown in Fig. 1 for a cell package optimized for 500 suns.

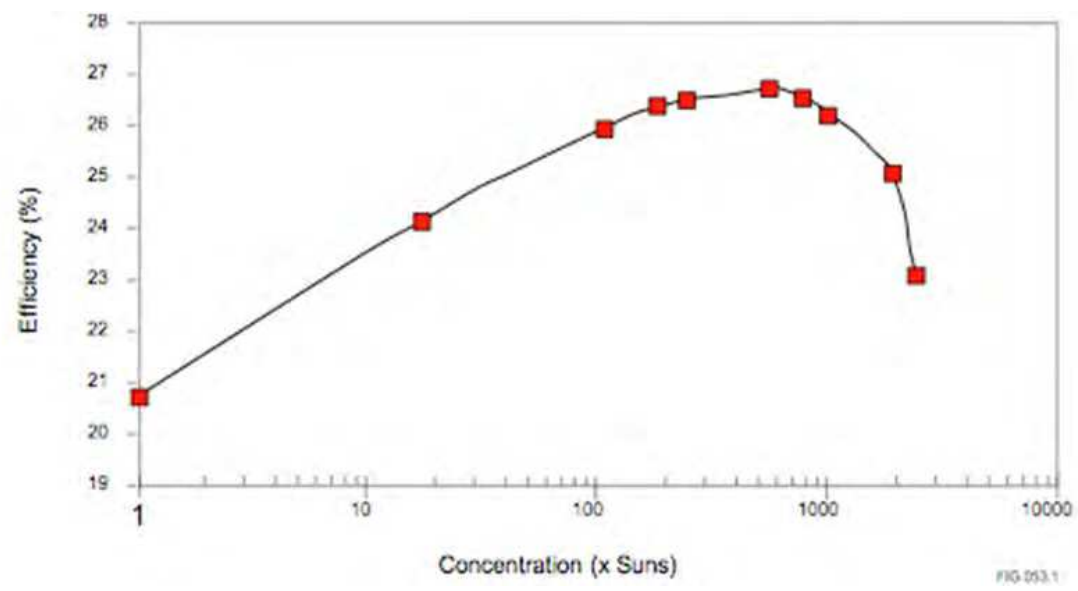

Fig. 1. Efficiency as a function of solar concentration for a mono-crystalline silicon solar cell. 
Unlike the flat-plate photovoltaic systems seen on roofs, solar concentrators must track the sun to focus light on to a solar cell throughout the day. Sun tracking increases the daily energy production above that of non-tracking flat-plate PV panels. However, electrical output drops dramatically if the sun is not focused on the cell, or if clouds block the sun. A concentrator photovoltaic (CPV) system comprises of a solar concentrator using lenses (Figure 2), or mirrors (Figure 3), a tracking mechanism, solar cells, and a heat sink.

On a per-area basis, PV cells are the most expensive components of a PV system. A concentrator makes use of relatively inexpensive materials such as plastic lenses and metal housings to capture the solar energy shining on a large area and focus that energy onto a smaller area - the solar cell area. Concentrator PV systems have several advantages over flat-plate systems. First, concentrator systems reduce the size or number of cells needed and allow much higher efficiency multi-junction tandem designs that use expensive processing and materials that would otherwise be cost prohibitive. Also, concentration reduces, by the concentration ratio, the amounts needed of materials with constrained availability (e.g, Ge, Ga), enabling sustainability in very large penetration scenarios (Fthenakis, 2010). Second, a solar cell's efficiency increases under concentrated light, as shown in Fig. 1. Third, a concentrator PV module can be made of small individual cells. This is an advantage because it is harder to produce large-area, high-efficiency solar cells than it is to produce small-area cells. However, challenges exist for concentrators. First, the required concentrating optics are more expensive than the simple covers needed for flat-plate solar systems, and concentrators must track the sun throughout the day and year to be effective. Thus, achieving higher concentration ratios, via reflectors or lenses, entails complex tracking mechanisms and more precise controls. To be cost effective, the additional electricity generated by concentrator systems must outweigh the additional system component costs.

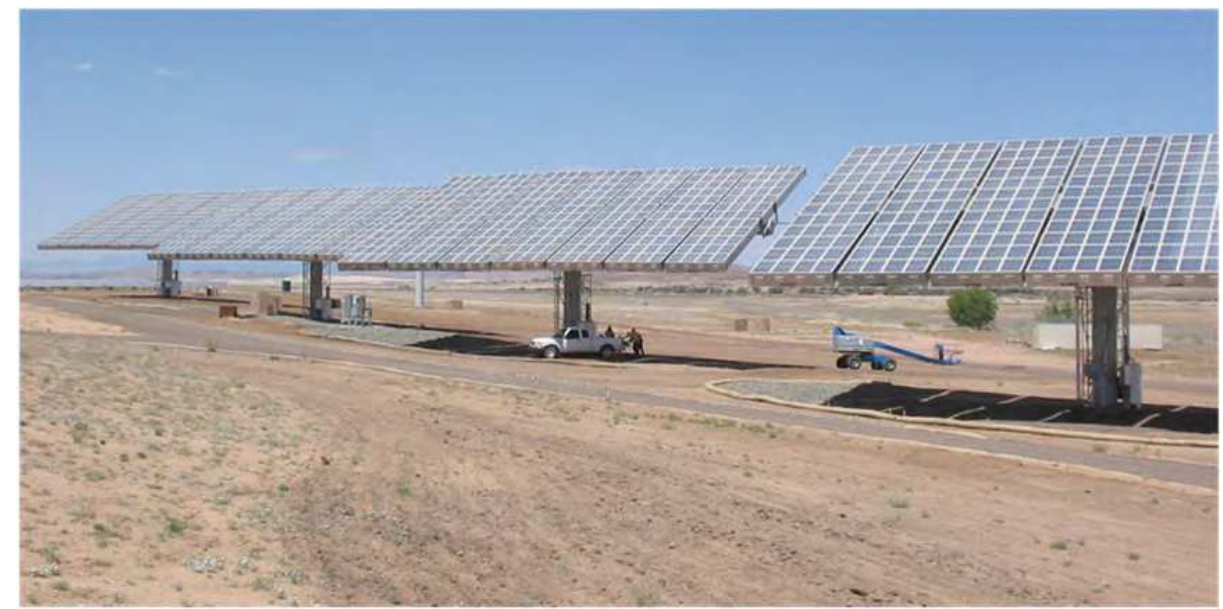

Fig. 2. Several 35-kW CPV systems built by Amonix in Torrance, California were installed at a Public Service power plant in Arizona. The system uses Fresnel lenses to concentrate sunlight onto high efficiency silicon solar cells. The pickup truck in the shade gives an idea of size of this installation. 


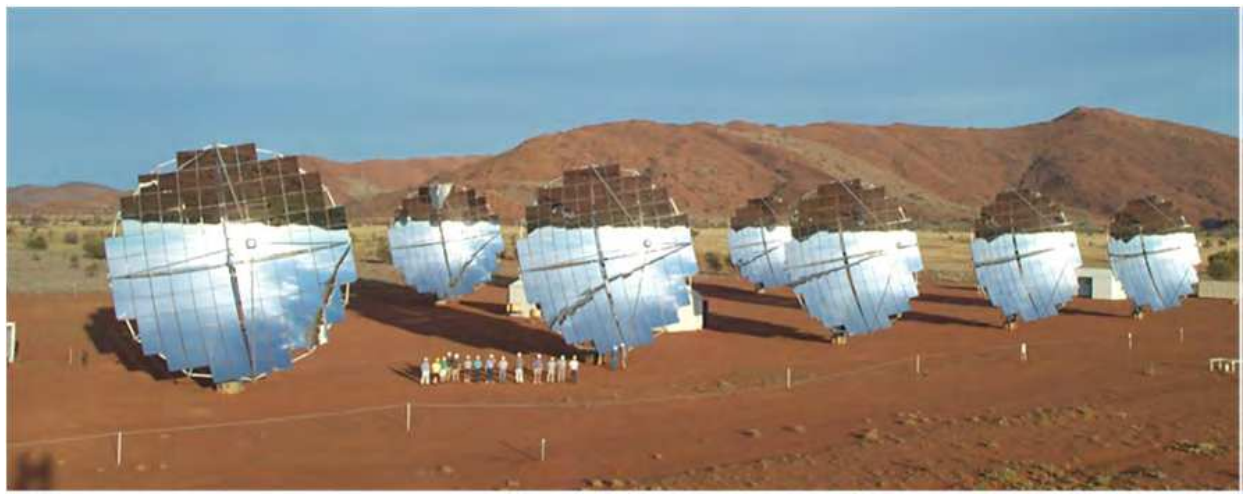

Fig. 3. Several 25-kW CPV systems built by Solar Systems in Hawthorn, Australia, and installed on aboriginal land. These systems use mirrors for concentrating sunlight onto silicon solar cells---see www.solarsystems.com.au The people in the foreground give an idea of the system's size (photo by R. McConnell).

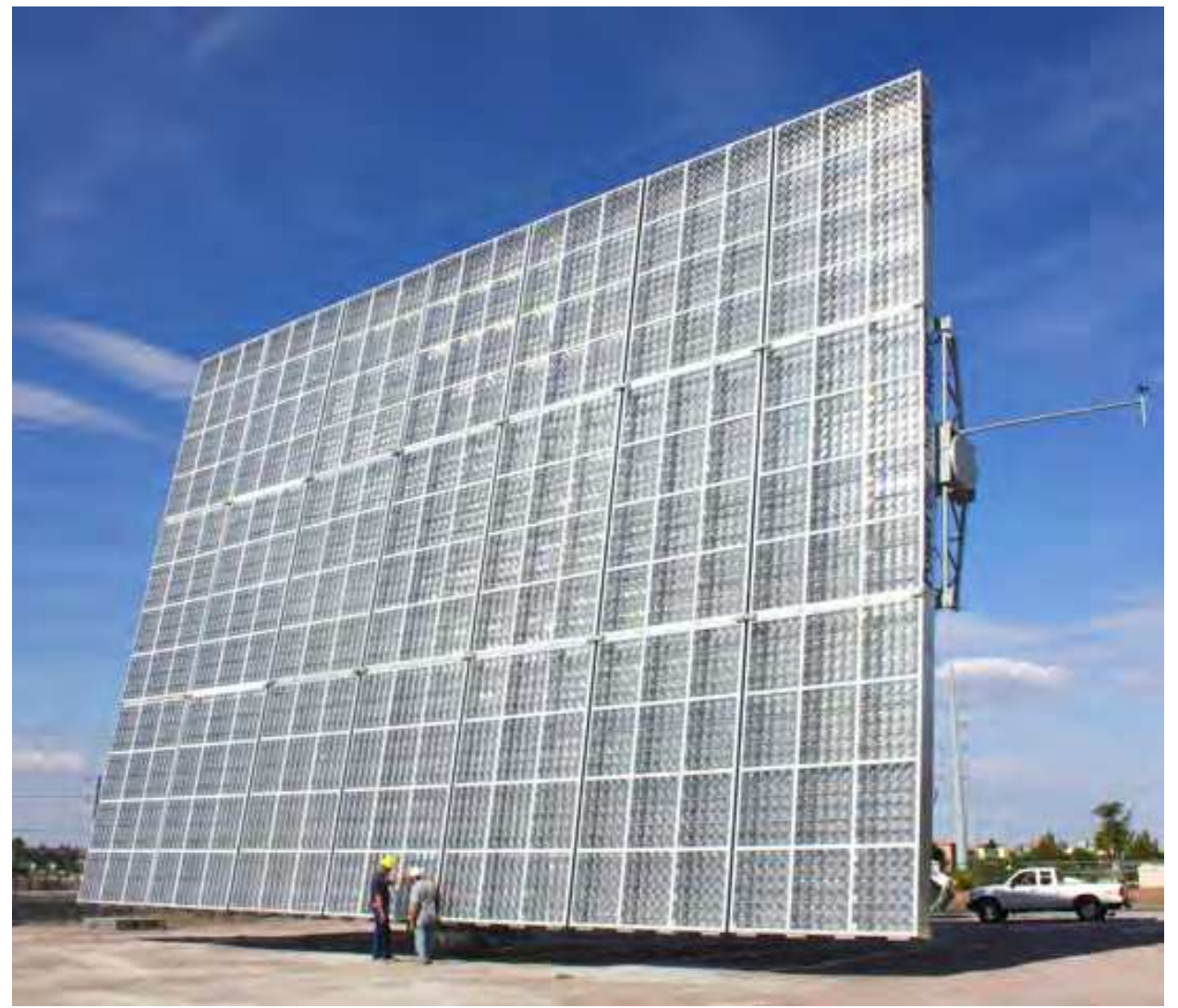

Fig. 4. The Amonix 770060 kWac System uses high efficiency multijunction solar cells. 
The most promising lens for PV applications is the Fresnel lens, which uses a complex sawtooth design to focus incoming light. When the teeth run in straight rows, the lenses act as line-focusing concentrators. When the teeth are arranged in concentric circles, light is focused at a central point. However, no lens can transmit $100 \%$ of the incident light. Typical lenses can transmit $90 \%$ to $95 \%$, and in practice, many transmit less. Furthermore, concentrators cannot focus diffuse sunlight, which makes up about $30 \%$ of the solar radiation in some locations. High concentration ratios also introduce a heat problem. When solar radiation is concentrated, so is the amount of heat produced. Cell efficiencies decrease as temperatures increase, and higher temperatures also threaten the long-term stability of solar cells. Therefore, the solar cells must be kept cool in a concentrator system, requiring sophisticated heat transfer designs (EERE, 2011).

As these photographs show, typical CPV systems are large, and more suitable for a utility than for private customers. Some companies, however, are developing smaller CPV products for rooftop markets. In the 1980s, the U.S. Department of Energy and the Electric Power Research Institute, funded CPV projects for utility applications until both organizations curtailed their CPV studies in the early 1990s as rooftop PV began to dominate the markets. Amonix, founded in 1989, built on these early studies and continued developing its technology despite a lack of utility customers. Thus, in 2005, Amonix spearheaded the development of a $10 \mathrm{MW} /$ year production facility in Spain, in a joint venture with the developer, Guascor. In 2011, Amonix completed the biggest CPV project in North America, a 5 MW plant using 84 Amonix 7700 trackers (Figure 4), in Hatch, New Mexico. For two decades, Amonix has been persistent and innovative in developing several generations of CPV designs leading to these successes in the utility market.

\section{Conversion efficiencies}

CPV systems are likely to be relatively low cost electricity generators because the expensive solar cells are replaced with less costly structural-steel holding mirrors or lenses. However, early CPV systems showed the importance of optical efficiencies as optical losses sometimes lowered the efficiency of CPV systems by $15 \%$ to $20 \%$. Today's CPV systems incorporating highly efficient III-V silicon solar-cells have system efficiencies approaching $29 \%$. The costs of installed CPV systems today are comparable to those of utility-scale flat-plate PV systems. However, further improvement of III-V solar cells, now about $42 \%$ efficient (Figure 5), is still possible since these efficiencies are far below the physical limits for converting sunlight into electricity.

Research on multijunction solar cells began in the 1980s as part of the US Department of Energy's effort to explore new solar-cell materials and new solar-conversion processes to improve cell efficiency. A single- junction solar cell is tuned to only one wavelength of the solar spectrum, so that its maximum efficiency is attained just at that color. The term semiconductor junction refers to the interface between a p-type semiconductor material and an n-type material. $\mathrm{P}$ and $\mathrm{n}$ denote the semiconductor's charge- carriers, reminding us that solar cells behave like batteries in having positive terminals, negative terminals, and in generating direct current. Early researchers on solar cells calculated that an infinite number of junctions would be the most effective means to harvest every color in the solar spectrum, and, theoretically, such a stacked set of junctions could convert more than $80 \%$ of the 
sunlight into electricity. Yet the first monolithic two-junction solar cell, fabricated almost three decades after the discovery of the modern solar cell, demonstrated efficiencies less than that of a single-junction cell. Major problems with materials and difficulties in creating a tunneling diode interconnect between junctions hindered success in making the first monolithic two-junction solar cells. These multi-junction PV technologies are based on elements in columns III and V of the periodic table; accordingly, they are often referred to as III-V solar cells. These high efficiency cells found a commercial niche in space-power markets. Today, almost every commercial- and defense-satellite, as well as the Mars Rover instrumentation-packages, use multi-junction III-V solar cells as their sources of electrical power. Just before the turn of the century, collaborative research and development by the National Renewable Energy Laboratory and Spectrolab, a Boeing company, demonstrated a three-junction solar cell with a higher efficiency than that of two-junction cells. Efficiencies now are $41.6-42.4 \%$ in the laboratory, with commercial cells showing $38 \%$ efficiency, and the promise of affordable costs is materializing. As shown in Table 1, performance pays, and module efficiencies of $32 \%$ could lead to system costs of $\$ 2.5 / \mathrm{W}$ and electricity cost in the southwestern US of only 6 cents/kWh (Algora, 2004). Capturing those economic benefits involves replacing the crystalline silicon-solar cells in essentially identical solar-concentrator structures with new high-efficiency III-V multi-junction cells.

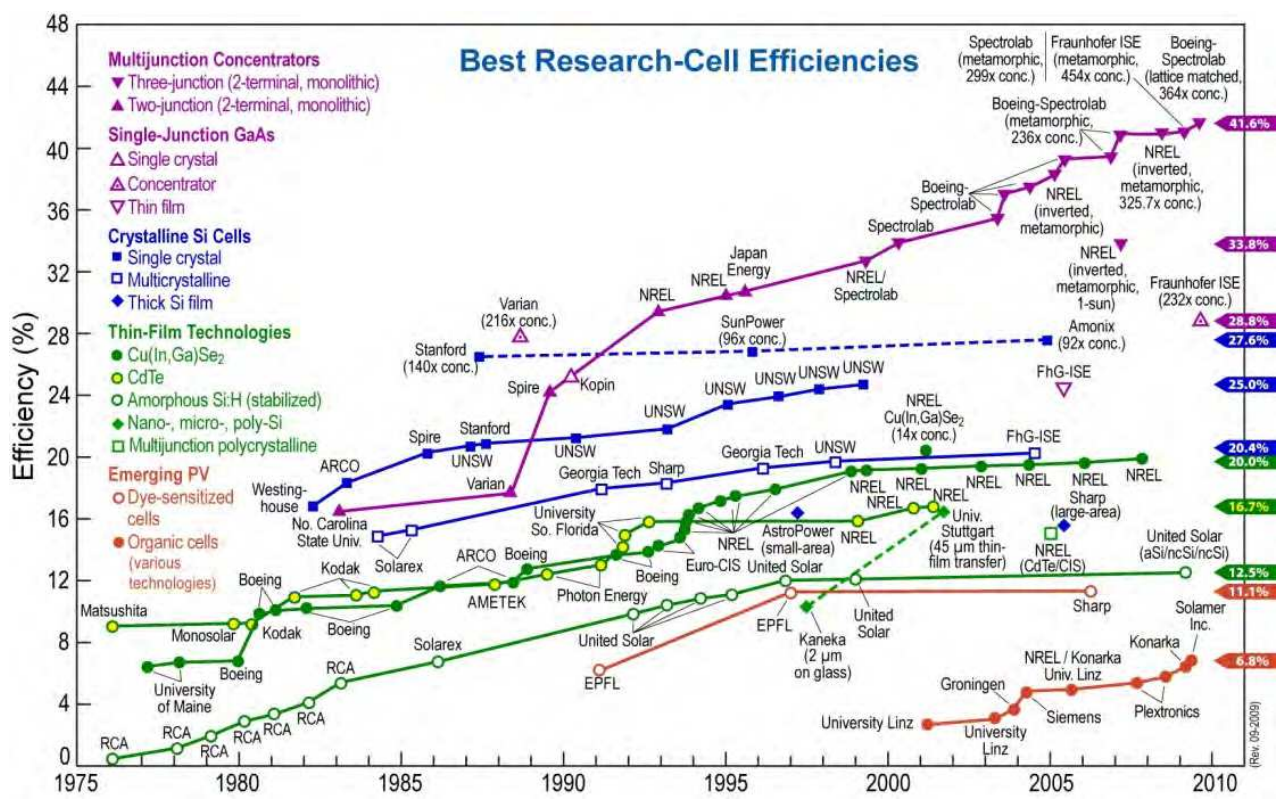

Fig. 5. Record efficiencies for different types of solar cells in the laboratory (Source: NREL). 


\begin{tabular}{|c|c|c|c|c|}
\hline System size & MW & 10 & 12.5 & 16 \\
\hline Module price & $\$ / W_{\mathrm{dc}}$ & 4.13 & 3 & 1.56 \\
\hline Cell efficiency & $\%$ & $26(\mathrm{Si})$ & $32(\mathrm{III}-\mathrm{V})$ & 40 (III-V) \\
\hline Module size & $\mathrm{kW}_{\mathrm{pdc}}$ & 40 & 50 & 64 \\
\hline Module efficiency & $\%$ & 20 & 25 & 32 \\
\hline Installed system price & $\$ / W_{\mathrm{dc}}$ & 5.95 & 4.3 & 2.52 \\
\hline LCOE & $\$ / k^{2} h_{a c}$ & $0.15-0.27$ & $0.10-0.15$ & $0.06-0.11$ \\
\hline
\end{tabular}

Table 1. Benchmark (10-MW) system parameters and impact of efficiency of multijunction (III-V) solar cell on a reference solar-concentrator PV utility system (Algora, 2004).

However, companies want to be sure that these new multijunction solar cells will operate reliably in their CPV systems because they typically function at higher voltages, generate higher current, and behave differently under environmental temperature cycles and humidity than do crystalline silicon solar cells. While reliability is best confirmed by decades of field operation, accelerated aging test procedures with qualification standards provide the optimum engineering alternative to minimize risks to reliability.

\section{CPV reliability}

Flat-plate crystalline silicon technologies have been renowned for their reliability in generating electricity for decades. What is often forgotten is that before flat-plate PV environmental tests were established in the early 1980s, some field projects of these systems failed terribly. Standards organizations afford an important service for all technology development by providing a forum for companies, customers and independent engineers to create a set of agreed-upon qualification tests for identifying weaknesses in products before they are marketed. Qualification standards, especially military standards, were critical to the success of space solar-cells developed for defense satellites in the 1960s and 1970s. However, with the first efforts to bring space PV down to earth, project leaders noted the inadequacy of the space test standards for terrestrial PV systems. Programs begun in the early 1980s at the Jet Propulsion Laboratory successfully developed terrestrial qualification standards for crystalline silicon flat-plate PV technologies. Today, crystalline silicon solar cells are renowned for their long-term reliability, and few people are aware of the early disasters.

Many early CPV systems suffered the same fate in that reliability was a serious issue. Electrical- and electronic-engineers developing PV systems and PV standards were unaccustomed to solving mechanical engineering problems or developing standards for large mechanical structures. In the late 1980s, Sandia National Laboratories devised a set of environmental stress tests (termed accelerated environmental testing) for CPV systems based on their early field tests funded by the U.S. Department of Energy. This work was the basis for the first CPV qualification standard developed in the late 1990s and was published in 2001 by the International Electrical and Electronics Engineers (IEEE) standards organization. This first qualification standard was most suitable for concentrator PV systems using Fresnel lenses, typical of many U.S. CPV designs (Ji and McConnell, 2006). A new qualification standard for CPV was published in 2007 by The International Electrotechnical Commission (IEC), the world's leading organization in preparing and publishing international standards for all electrical-, electronic-, and related technologies. All IEC standards are fully consensus-based and represent the needs and expectations of key stakeholders from every nation participating in IEC work. Some key CPV stakeholders are 
the companies who design and manufacture CPV systems; another group consists of customers and project developers who specify, purchase, or install systems. As the CPV market rapidly emerged, the interest in developing IEC CPV standards increased by leaps and bounds. The IEC CPV Working Group 7 (WG7) has over 60 members from 15 countries, linking companies, test laboratories and customers in developing and publishing international CPV standards. WG7 is one of the working groups within TC82, the IEC technical committee for all solar photovoltaic energy systems. The scope of IEC 's WG7 is to formulate international standards for photovoltaic concentrator systems, including cells, receivers, modules, arrays, assemblies, trackers, power plants, and solar simulators; this effort encompasses the general areas of safety, photovoltaic performance, qualification and environmental reliability tests, as well as thermal performance, high-voltage performance, fault resistance, and fault-tolerant design (McConnell et al., 2011).

\section{Life-Cycle Assessment}

Life cycle assessment (LCA) is an analytical tool used to measure material- and energyinputs and emissions, and waste-outputs throughout the entire life-cycle stages of a product or process, ultimately aiming to evaluate the system's environmental- and health-impacts. LCA is especially useful in comparing power-generation technologies.

Fthenakis and Kim (2011) undertook a life-cycle assessment of Amonix 7700 CPV based on detailed bill of materials, fuel- and electricity-usage, and operational data from Amonix Inc. The life cycle starts with the acquisition of materials, encompasses their production, the manufacturing of components, their transportation, assembly, and installation, their operation/maintenance, and then ends with their disposal (Figure 6).

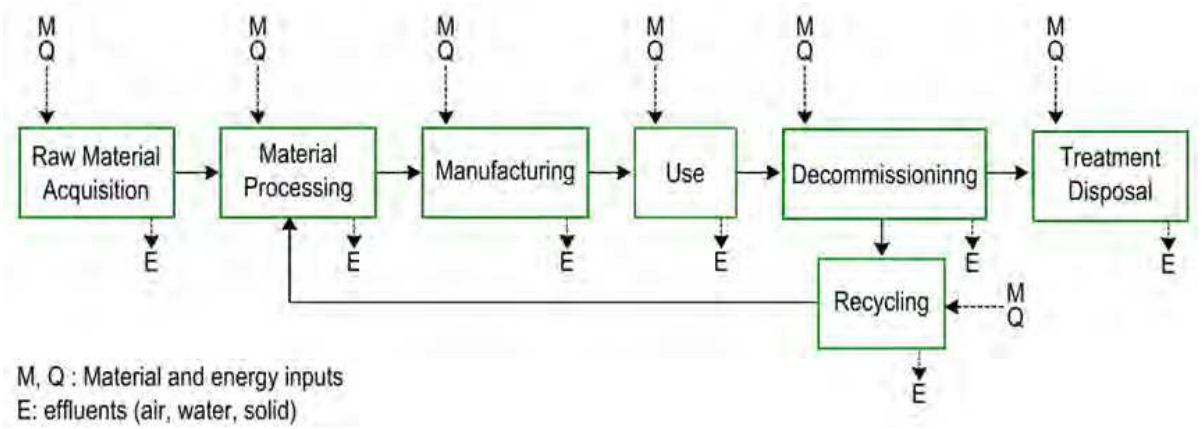

Fig. 6. The Life Cycle of Photovoltaic Systems.

The system consists of seven concentrating module units, so-called MegaModules, mounted on a two-axis tracker (Fig. 4). Sunlight is concentrated onto 7560 focal spots at a ratio of 500:1. This system uses multi-junction GaInP/GaInAs/Ge cells grown on a germanium substrate rated at $37 \%$ efficiency under the test conditions of $50 \mathrm{~W} / \mathrm{cm}^{2}, 25^{\circ} \mathrm{C}$, and AM 1.5D. With an aperture area of $267 \mathrm{~m}^{2}$, the capacity of this unit corresponds to $53 \mathrm{~kW}_{\mathrm{p}} \mathrm{AC}$ power under the test conditions of the Photovoltaics for Utility Scale Applications (PVUSA), i.e., $850 \mathrm{~W} / \mathrm{m}^{2}$ direct normal incidence (DNI), $20^{\circ} \mathrm{C}$ ambient temperature, and $1 \mathrm{~m} / \mathrm{sec}$ wind velocity. With multiple increases in system component efficiencies (e.g. cell, lens, heat sink, interconnect, inverter, etc.) Amonix found the same unit produced up to $63 \mathrm{~kW}_{\mathrm{p}} \mathrm{AC}$ power in 2011 under the same test conditions. 
The materials composition and mass balance of the Amonix 7700 system are detailed elsewhere (Fthenakis and Kim, 2011). The MegaModules (36\%) and tracker (58\%) account for most of the components, while steel $(75 \%)$, concrete $(11 \%)$, and aluminum $(11 \%)$ dominate the material usages. The cumulative energy-demand for all the parts of the system were calculated, and contrasted with the energy generated by the system. Fthenakis and Kim (2011) determined the electricity generation of the Amonix 7700 based on the energy production of a $7500 \mathrm{CPV}$ system in Las Vegas over a year, accounting for the following potential losses in field performance: Additional soiling (2\%), ac wiring and transformer losses $(2 \%)$, availability $(1 \%)$, wind stow $(0.5 \%)$, shading $(0.5 \%)$ and losses from the limit on elevation angle $(0.8 \%)$. Their analysis yielded $144,000 \mathrm{kWh}$ /year of electricity generation for Las Vegas where the DNI with a 2-axis tracker is $2600 \mathrm{kWh} / \mathrm{m}^{2} / \mathrm{yr}$. Table 3 gives the EPBT and GHG emissions estimated for different parts of the US-SW.

The greenhouse gas (GHG) emissions during the life cycle stages of the Amonix $7700 \mathrm{HCPV}$ system were estimated as an equivalent of $\mathrm{CO}_{2}$, using an integrated time-horizon of 100 years . Unlike fixed, standard PV configurations in which the emissions mostly are evolved during the production of solar cells, the tracking- and concentrating-equipment contributes the majority of the GHG emissions from this system. After normalizing for the electricity generated, the system will generate $26-27 \mathrm{~g} \mathrm{CO}_{2}$-eq./ $\mathrm{kWh}$ during its 30 -year life-cycle (Table 2) under its current operating locations. Extending the system's life to 50 years by properly maintaining it, and replacing the solar cells and Fresnel lenses every 25 years, will lower its life-cycle emissions to about $16 \mathrm{~g} \mathrm{CO}_{2}$-eq./ $\mathrm{kWh}$.

\begin{tabular}{|c|r|r|r|r|}
\hline Stage & Energy (MJ) & $\mathbf{0}$ & $\begin{array}{l}\text { GHG } \\
\text { (kg CO }\end{array}$-eq.) & \% \\
\hline Parts & $\mathbf{1 4 7 0 6 3 3}$ & $\mathbf{8 8 . 3}$ & $\mathbf{1 0 2 1 0 8}$ & $\mathbf{9 2 . 4}$ \\
\hline Cells & 14562 & 0.9 & 615 & 0.6 \\
\hline Foundation & 2341 & 0.1 & 430 & 0.4 \\
\hline Frame & 234218 & 14.1 & 16836 & 15.2 \\
\hline Fresnel lenses & 171974 & 10.3 & 9086 & 8.2 \\
\hline Heat Sink & 440089 & 26.4 & 31194 & 28.2 \\
\hline Tracker (Pedestal and tube) & 427106 & 25.7 & 31420 & 28.4 \\
\hline Inverter & 33395 & 2.0 & 2130 & 1.9 \\
\hline Transformer & 11973 & 0.7 & 566 & 0.5 \\
\hline Hydraulic drive & 117972 & 7.1 & 8912 & 8.1 \\
\hline Motor & 2056 & 0.1 & 113 & 0.1 \\
\hline Cables & 5278 & 0.3 & 265 & 0.2 \\
\hline Controller & 8907 & 0.5 & 498 & 0.5 \\
\hline Anemometer and Sensor & 762 & 0.05 & 43 & 0.04 \\
\hline Assembly/Installation & $\mathbf{1 6 2}$ & $\mathbf{0 . 0 1}$ & $\mathbf{1 2}$ & $\mathbf{0 . 0 1}$ \\
\hline Operation/Maintenance & $\mathbf{1 1 1 8 3 0}$ & $\mathbf{6 . 7}$ & $\mathbf{2 4 6 3}$ & $\mathbf{2 . 2}$ \\
\hline Transportation & $\mathbf{6 1 3 6 4}$ & $\mathbf{3 . 7}$ & $\mathbf{4 4 8 0}$ & $\mathbf{4 . 1}$ \\
\hline End-of-Life decommissioning & $\mathbf{2 0 7 4 5}$ & $\mathbf{1 . 2}$ & $\mathbf{1 5 1 2}$ & $\mathbf{1 . 4}$ \\
\hline Total & 1664733 & 100.0 & 110575 & 100.0 \\
\hline
\end{tabular}

Table 2. Breakdown of the Life Cycle Primary-Energy Demand (From Fthenakis and Kim, 2011). 


\begin{tabular}{|c|c|c|c|c|c|c|c|}
\hline \multirow[t]{2}{*}{ Location } & \multirow{2}{*}{$\begin{array}{l}\text { DNI with 2- } \\
\text { axis tracker } \\
(\mathrm{kWh} / \mathrm{m} 2 / \mathrm{yr})\end{array}$} & \multicolumn{2}{|c|}{$\begin{array}{l}\text { Energy } \\
\text { generation } \\
(\mathrm{MWh} / \mathrm{yr})\end{array}$} & \multicolumn{2}{|c|}{$\begin{array}{c}\text { EPBT } \\
(\mathrm{yrs})\end{array}$} & \multicolumn{2}{|c|}{$\begin{array}{l}\text { GHG emissions } \\
\left(\mathrm{g} \mathrm{CO}_{2} \text {-eq/kWh) }\right.\end{array}$} \\
\hline & & 2009 & 2011 & 2009 & 2011(est) & 2009 & 2011(est) \\
\hline Las Vegas, NV & 2600 & 144 & 178 & 0.9 & 0.8 & 26 & 21 \\
\hline Phoenix, AZ & 2480 & 136 & 170 & 0.9 & 0.8 & 27 & 22 \\
\hline Glendale, $\mathrm{AZ}$ & 2570 & 139 & 176 & 0.9 & 0.8 & 27 & 21 \\
\hline
\end{tabular}

Table 3. EPBT- and GHG-emissions of Amonix 7700 for 2009 (from Fthenakis and Kim) and estimates for 2011 based on increased energy generation.

These EPBT- and the GHG-emissions from the life-cycles of ground-mount PV modules were estimated to be to 1.8 years and $39 \mathrm{~g} \mathrm{CO}_{2}$-eq./ $\mathrm{kWh}$, respectively, when operating in south-facing latitude tilt under the optimal angle insolation of Phoenix-- $2370 \mathrm{kWh} / \mathrm{m}^{2} / \mathrm{yr}$. Thus, for both parameters, the Amonix $7700 \mathrm{HCPV}$ has a significant advantage over the flat, fixed crystalline silicon solar-cell systems (Fthenakis and Kim, 2011).

\section{CPV following wind-turbine developments}

One renewable energy technology developed successfully is wind-turbine electricity generation. In the 1970s, wind systems and PV systems started out pretty much on the same footing, viz., only a few experimental systems for each were installed around the world. Today, there are roughly 10 times more installed wind-energy systems than PV systems Why did wind-energy deployment surpass that of photovoltaics? One reason was that wind developers quickly demonstrated the economies of production just as a market opportunity appeared. Fabrication facilities are relatively cheap for both wind- and CPV-systems compared with PV manufacturing facilities. Wind-turbine and CPV production facilities look more like automobile assembly lines (Figure 7) (McConnell, 2002). Early market incentives in California helped developers of wind- developers of wind-systems to move their technologies forward, reducing costs, and acquiring valuable operational experience that improved reliability. Their engineers formulated their system's qualifications standards during this time; like early PV technologies, wind systems often demonstrated poor reliability until their certification standards were established and required in the marketplace.

There are some noteworthy similarities between wind-energy systems and CPV systems (McConnell, 2002). They both employ relatively common materials, particularly steel. The costs of wind systems are typically less than $\$ 1$ per watt; they are mainly dependent on the cost of steel, while flat-plate PV mostly is linked to the availability and cost of expensive semiconductor silicon. However, solar-concentrator structures also are amenable to an autoassembly type of production, and CPV developers estimate that the costs of CPV production facilities are closer to those of wind systems than to those of flat-plate-PV production facilities. In the EPRI's early cost studies, the expense of CPV production facilities were estimated on the same costing basis as those of the crystalline- and amorphous-silicon facilities, to be about $\$ 28$ million for a 100-MW per year installation, that is, about a quarter of the cost of the conventional silicon-PV facilities (Whisnant and Wright,1986). This lower investment can entail a faster scale-up of manufacturing facilities because risk to investors is relatively smaller than that entailed in investing in conventional photovoltaic-production facilities. 


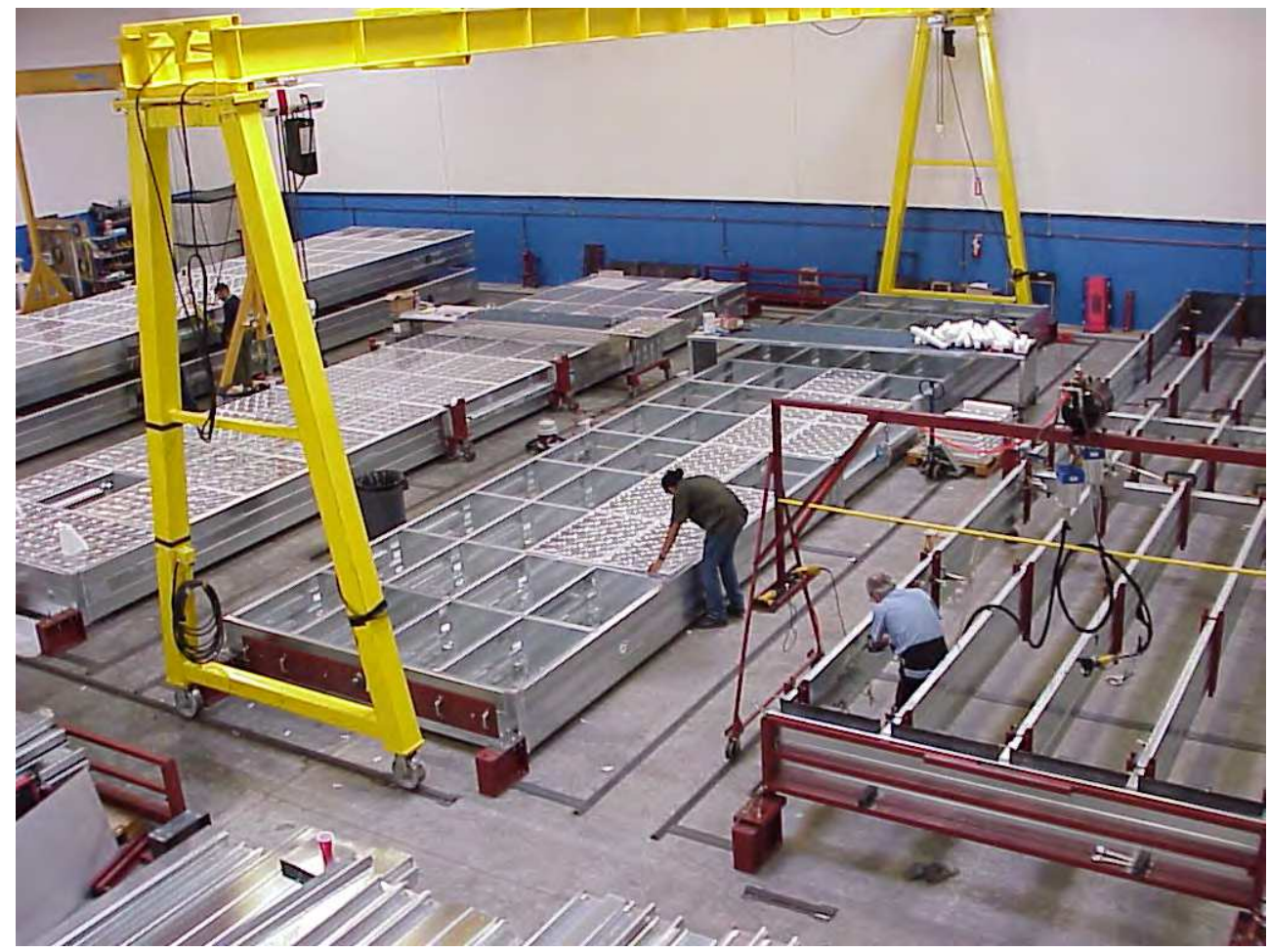

Fig. 7. An early Amonix production facility in Los Angeles.

Further, studies in Spain and Israel estimate that the costs of CPV installed system costs will, like those for wind systems, finish below $\$ 1$ per watt when gigawatt levels of CPV production are reached (Algora 2004; Faiman et al., 2005). Both CPV- and wind-energytechnologies are modular, just like flat-plate PV modules although the sizes are different. Wind units are now megawatts in size, while CPV units are typically 10 s of kilowatts. Both wind- and CPV-systems have moving parts, and moving parts have not limited the success of wind systems. Finally, wind systems first penetrated the energy marketplace in sites with very high, steady winds while CPV systems almost certainly will enter markets in locations with lots of sunlight and few clouds, similar to the world's desert climates and the southern US climates. 


\section{Low-cost hydrogen from hybrid solar-concentrator PV systems}

In addition to generating clean, carbon-free solar electricity at low cost, concentrator PV systems potentially can produce hydrogen through the electrolysis of water. There are several reasons why the generation of electrolytic hydrogen from solar energy is critically important to the world's long-term energy needs. The feedstock (water) and solar energy both are carbon free, having no adverse impact on global warming. In addition, there is the potential to generate hydrogen near its markets, thus minimizing transportation costs. Previously, the principal criticism of photovoltaics for generating hydrogen has been the high cost of PV electricity and the inefficiencies of the conversion processes, particularly in the photovoltaic process.

As we discussed earlier, concentrator photovoltaic systems potentially can generate cheaper electricity, primarily by utilizing high-efficiency multi-junction III-V solar cells. But it is the heat boost from concentrator PV systems that will dramatically improve and enhance the electrolysis efficiency of water in a high-temperature solid-oxide electrolyzer. This heat boost, $\sim 40 \%$, measured by Solar Systems in Australia above $1100^{\circ} \mathrm{C}$ (Lasich, 1997, 1999), also was estimated in theoretical analyses (Licht, 2003). This new pathway provides significant engineering- and economic-benefits for generating electrolytic hydrogen from solar energy, thereby creating opportunities for PV directly to contribute to future transportation markets with low-cost hydrogen, or by producing liquid hydrogen-carrier fuels, such as methanol (Lewis, 2006). On-site storage of hydrogen in inexpensive steel tanks (similar to propane tanks) for on-demand electricity generation favorably will invite a fresh comparison with other technologies for storing electricity like batteries, pumped storage, flywheels, compressed air, and superconducting magneticenergy storage. Solar-to-hydrogen conversion efficiencies of $40 \%$, including optical losses, may be attainable in the near-term using high efficiency III-V multijunction solar cells, where efficiencies of $50 \%$ and higher are realistic targets within 5- to 10-years. These figures-of-merit are dramatically higher, by roughly a factor of 3 or 4, than those of any other previously considered methods for generating electrolytic hydrogen from solar electricity (16). Based on the long-term potential for concentrator PV systems to be massproduced at costs of less than $\$ 1 / \mathrm{W}$, these values will lead to the costs of hydrogen production being comparable with the energy costs of gasoline, recognizing that $1 \mathrm{~kg}$ of hydrogen has the energy equivalent of one U.S. gallon of gasoline (McConnell et al, 2005a; 2006).

\subsection{System description}

This approach first proposed by Solar Systems in Australia employs a dish concentrator that reflects sunlight on to a focal point (Figure 8).

The reflected infrared radiation is gathered by a fiber optics "light pipe" and conducted to the high-temperature solid-oxide electrolysis cell. The electrical output of the solar cells also powers the electrolysis cells. About 120 megajoules are needed, either in electrical- or thermalform, or both, to electrolyze water and generate $1 \mathrm{~kg}$ of hydrogen. The result is that more of the solar energy is used for hydrogen production. The additional costs for the components of this hybrid solar- concentrator, the spectral splitter, and fiber-optic light pipe, are relatively small compared with the boost in hydrogen production, as we discuss later. 


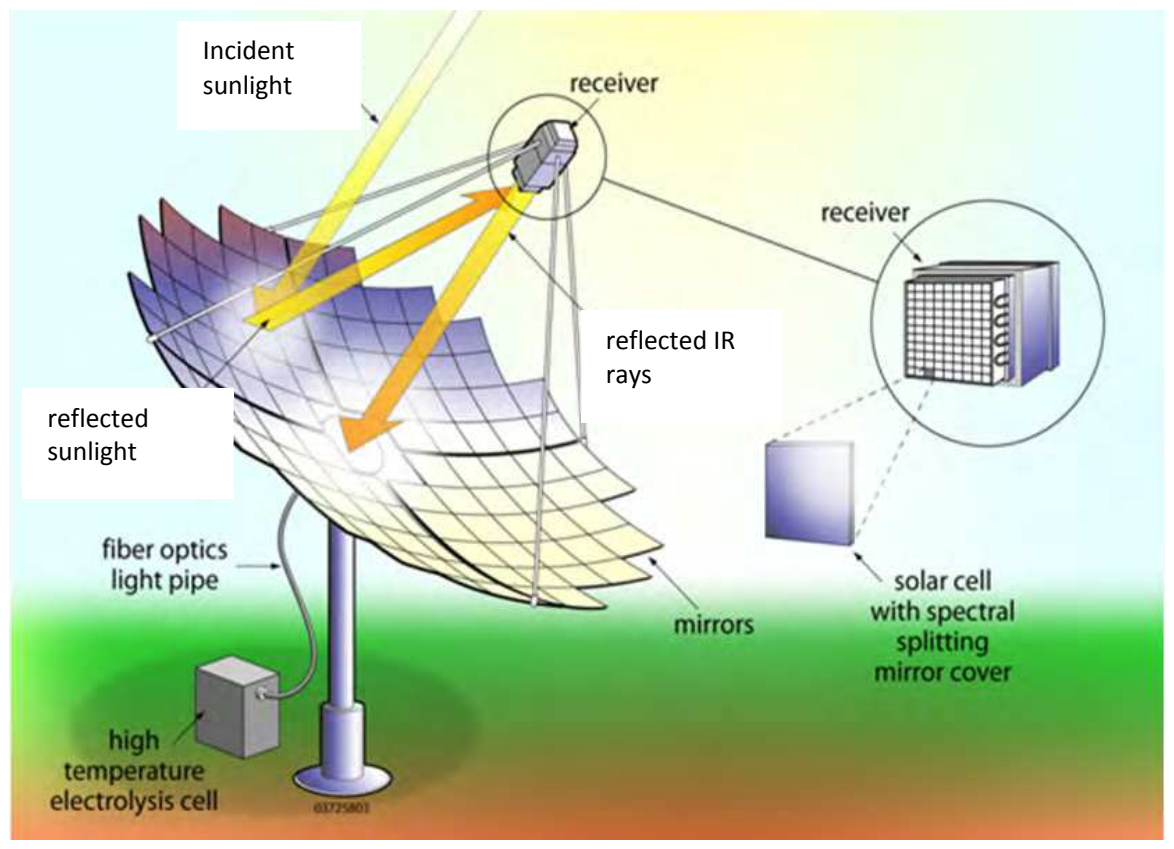

Fig. 8. Schematic of system showing sunlight reflected and focused on the receiver, with reflected infrared directed to a fiber-optics light pipe for transport to a high-temperature solid-oxide electrolysis cell. Solar electricity is sent to the same electrolysis cell that uses both heat and electricity to split water. A spectral splitter at the focal point reflects infrared solar radiation and transmits the visible sunlight to high-efficiency solar cells behind the spectral splitter. (Source: Thompson, McConnell and Mosleh, 2005).

All components shown in Figure 8 were tested in the mid-1990s as detailed previously (Faiman et al, 2005; Lasich, 1997; 1999; McConnell, 2005a, 2005b, 2008) on a small scale. The solar concentrator was a paraboloidal dish $1.5 \mathrm{~m}$ in diameter with two-axis tracking, and capable of more than 1000-suns concentration. The full dish was not needed and portions were appropriately shaded. At that time, the solar cell was a GaAs cell with an output voltage of $1-$ to $1.1-\mathrm{V}$ at maximum power point with a measured efficiency of about $19 \%$. The voltage was an excellent match for direct connection to the electrolysis cell when operating at $1000^{\circ} \mathrm{C}$. The tubular solid-oxide electrolysis cell was fabricated from yttriastabilized zirconia (YSZ); the cell had platinum electrodes since the test temperature was higher than that of typical solid-oxide cells. Figure 9 shows a schematic of the operation of solid-oxide electrolysis cells. 


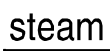

hydrogen

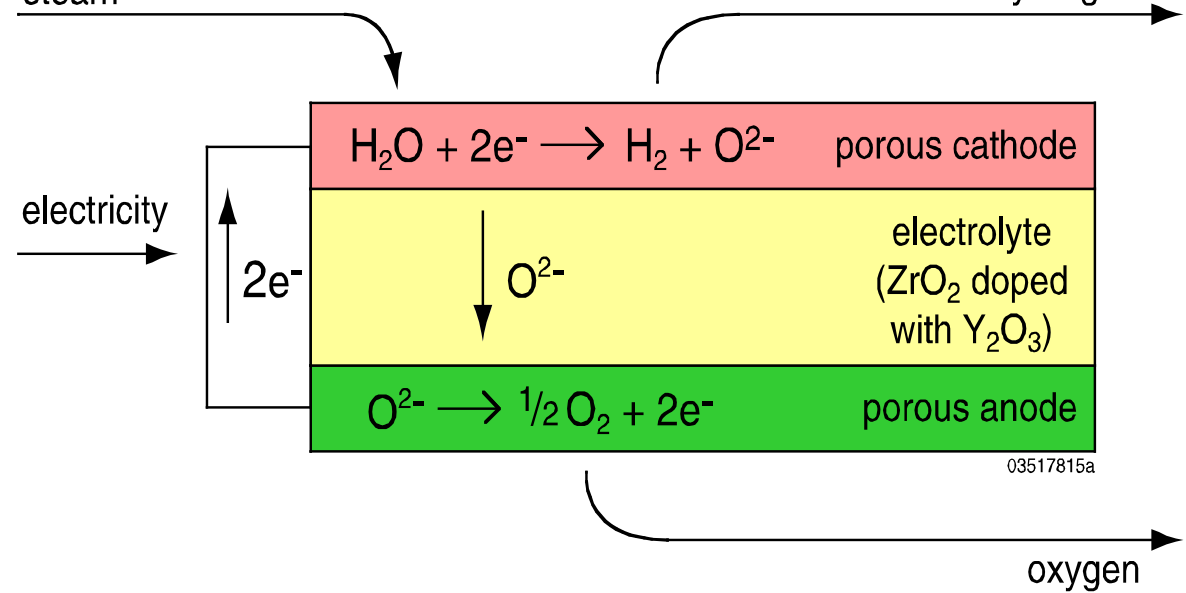

Fig. 9. Schematic of high-temperature electrolysis in a solid-oxide cell. The geometry can be planar or tubular as it was for the first demonstration of the hybrid solar-concentrator PV system. Operating the electrolysis cell in reverse corresponds to electricity- and heatproduction in solid-oxide fuel cell operation.

A metal tube surrounds the cell to uniformly distribute the solar flux over the cell's surface. The test occurred over two hours of operation with an excess of steam applied to the electrolysis cell. The output stream of unreacted steam and generated hydrogen was bubbled through water, and the hydrogen was collected and measured. During a definitive 17 minutes of system operation in steady state, $80 \mathrm{~mL}$ of hydrogen was collected. The ratio of the thermoneutral voltage of $1.47 \mathrm{~V}$ to the measured electrolysis cell voltage of $1.03 \mathrm{~V}$ was 1.43 , corresponding to a boost of more than $40 \%$ in hydrogen production attributable to the input of thermal energy. This was confirmed by the energy balance. Combining the optical efficiencies of the concentrator dish (85\%), solar-cell efficiency, and thermal- energy boost, the efficiency of the total system in converting solar energy to hydrogen was $22 \%$. When these measurements were made in the mid-1990s, the efficiency was almost three times better than that recorded for any other technology converting solar energy to hydrogen.

These early tests were not conducted with the most efficient solar cells then available. The record efficiency then was about $30 \%$ for a laboratory cell (Figure 5) and they were not easily obtainable. Today's record efficiency is $42 \%$, and while commercial cells are $37-38 \%$ efficient. Therefore, a $40 \%$ solar-to-hydrogen efficiency is anticipated in the near term, assuming a heat boost of $40 \%$, a multi-junction solar-cell efficiency of $35 \%$, and an optical efficiency of $85 \%$. Such a multi-junction solar cell would yield a solar-to-hydrogen conversion efficiency of almost $50 \%$. As discussed previously, the theoretical electrochemical findings are consistent with these predictions, based on Solar Systems' early measurements (Licht, 2003).

\section{Discussion}

Today, electricity providers throughout the world are considering large-scale concentrator PV projects, some in the 100s of MW. In the future, a hybrid concentrator-PV system could generate both electricity and hydrogen for electric utilities. With low-cost tank storage on 
utility land, the solid-oxide electrolysis cell could be designed to operate in a regenerative mode, producing electricity from hydrogen during non-solar periods, thereby greatly increasing the value of solar electricity to utilities.

Fthenakis, Zweibel and Mason (2010) published a study on the feasibility of very-largescale photovoltaic systems in the southwestern US, and dispersed generation throughout the country. A renewable-energy electricity mixture comprising mainly of PV, CPV and CSP could, by the end of this century, supply $100 \%$ of year-round electricity demand, while a surplus of electricity during the sunny seasons can produce 260 billion $\mathrm{kg}$ of hydrogen by electrolysis. By adding 5.2 TW of PV dedicated to hydrogen production, a fleet of 5666 million plug-in hybrid vehicles, trucks, ships, and planes could be fueled by hydrogen.

With today's market entry of CPV systems for electricity production, the increasing efficiencies of solar cells now approaching 40\% with clearer ideas for attaining $50 \%$ efficient solar cells, and the opportunity to use wasted solar heat for augmenting solar electrolysis, this is a potential "leap frog" technology that may rapidly lower the cost of clean hydrogen.

\section{Conclusion}

We described CPV technologies based on high-efficiency III/V solar cells that will lower the cost of electricity production in sunny areas to parity with the present expense of grid electricity. In addition, CPV offers the future potential for enhancing the hydrolytic production of hydrogen by utilizing the thermal losses from generating electricity. We discussed the following reasons supporting the argument that CPV is a technology that will prove significantly beneficial throughout the world:

1. Short energy payback times support the potential for CPV to provide inexpensive electricity, competitive in utility markets.

2. The CPV community completed the first CPV-qualification standards in time to respond to market opportunities, while additional standards on safety, performance, and tracking are well underway.

3. The early success of wind energy technologies, similar in several respects to CPV technologies, augurs rapid success for CPV systems.

4. The possibility of efficiently producing hydrogen by splitting water using low-cost solar electricity opens future, clean pathways for storing solar electricity and generating transportation fuels.

\section{References}

Algora C., 2004. Chapter 6 in Next Generation Photovoltaics, edited by A. Marti and A. Luque, Institute of Physics Physics Publishing, Bristol and Philadelphia.

Archimedes, accessed Dec 72011 , http://www.math.nyu.edu/ crorres/Archimedes/Mirrors/Tzetzes.html

Backus, C. E., 2003. "A Historical Perspective on Concentrator Photovoltaics", Proceedings of the International Solar Concentrator Conference for the Generation of Electricity or Hydrogen, Alice Springs, Australia. 
EERE, 2011. US-DOE, Energy Efficiency and Renewable Energy, Concentrator Photovoltaic Systems,

http://www.eere.energy.gov/basics/renewable_energy/concentrator_pv_syste ms.html

Faiman, D., Raviv I. and Rosenstreich, R. 2005. "The Triple Sustainability of CPV with the Framework of the Raviv Model", Proceedings of the 20th European Photovoltaic Solar Energy Conference and Exhibition, Barcelona, Spain.

Fthenakis, V., Mason J.E., Zweibel K. 2010. “The technical, geographical, and economic feasibility for solar energy to supply the energy needs of the US", Energy Policy 27, 387-399.

Fthenakis V.M., "Sustainability of photovoltaics: The case for thin-film solar cells", Renewable and Sustainable Energy Reviews, 13, 2746-2750, 2009.

Fthenakis V.M., Kim H.C., "Life Cycle Assessment of High-Concentration PV Systems", Progress in Photovoltaics, in press.

Hartvigsen J. 2006. Private communication, also see www.ceramatec.com

Ji L. and McConnell R., 2006. "New Qualification Test Procedures for Concentrator Photovoltaic Modules and Assemblies", Proceedings of the 2006 IEEE $4^{\text {th }}$ World Conference on Photovoltaic Energy Conversion, Waikoloa, Hawaii.

Lasich, J., U.S. Patent No. 5658448, August 19, 1997

Lasich, J., U.S. Patent No. 5973825, October 26, 1999

Lewis, N. http://www7.nationalacademies.org/bpa/SSSC_Presentations_Oct05_Lewis.pdf, August 2006

Licht, S. 2003. "Solar Water Splitting to Generate Hydrogen. Fuel: Photothermal Electrochemical Analysis," J. Phys. Chem. B 107, 4253-4260.

McConnell, R. 2002. "Large-Scale Deployment of Concentrating PV: Important Manufacturing and Reliability Issues", Proceedings of the First International Conference on Solar Electric Concentrators, New Orleans, Louisiana, NREL/EL590-32461, May 2002.

McConnell, R., M. Symko-Davies and D. Friedman. 2006. "Multijunction Photovoltaic Technologies for High Performance Concentrators", Proceedings of the 2006 IEEE $4^{\text {th }}$ World Conference on Photovoltaic Energy Conversion, Waikoloa, Hawaii.

McConnell, R., S. Kurtz and M. Symko-Davies, 2005. “Concentrating PV Technologies: Review and Market Prospects", ReFOCUS, Elsevier Ltd, p. 35, July/August 2005.

McConnell, R.D., J. B. Lasich and C. Elam, 2005. “A Hybrid Solar Concentrator PV System for the Electrolytic Production of Hydrogen", Proceedings of the 20 th European Photovoltaic Solar Energy Conference and Exhibition, Barcelona, Spain, June 2005.

McConnell, R., 2008. Chapter 4 in Solar Hydrogen Generation, edited by K. Rajeshwar, R. McConnell and S. Licht, Springer Science+Business Media, LLC, New York, New York.

McConnell, R. et.al, 2011, "The CPV Standards Nexus", in preparation for the Eighth International Conference on Concentrating Photovoltaic Systems.

National Research Council and National Academy of Engineering. 2004. "The Hydrogen Economy", National Academies Press, Washington DC. 
Thompson, J. R., McConell, R.D. and Mosleh M., Cost Analysis of a Concentrator Photovoltaic Hydrogen Production System, International Conference of Solar Concentration for the Generation of Electricity or Hydrogen, 1-5 May 2005, Scottsdale, Arizona (NREL/CD-520-38172)

Whisnant, R., S. Wright, P. Champagne and K. Brookshire. 1986. "Photovoltaic Manufacturing Cost Analysis: A Required-Price Approach", Volume 1, 2, EPRI AP4369, Electric Power Research Institute, Palo Alto, CA. 


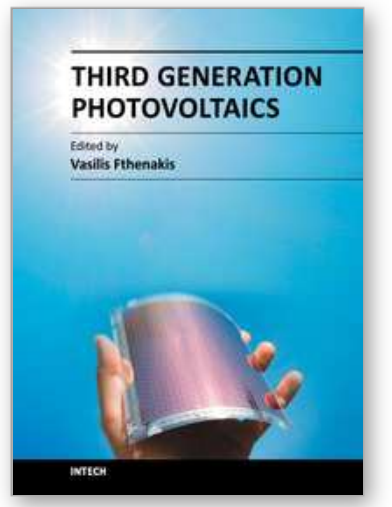

\author{
Third Generation Photovoltaics \\ Edited by Dr. Vasilis Fthenakis
}

ISBN 978-953-51-0304-2

Hard cover, 232 pages

Publisher InTech

Published online 16, March, 2012

Published in print edition March, 2012

Photovoltaics have started replacing fossil fuels as major energy generation roadmaps, targeting higher efficiencies and/or lower costs are aggressively pursued to bring PV to cost parity with grid electricity. Third generation PV technologies may overcome the fundamental limitations of photon to electron conversion in single-junction devices and, thus, improve both their efficiency and cost. This book presents notable advances in these technologies, namely organic cells and nanostructures, dye-sensitized cells and multijunction III/V cells. The following topics are addressed: Solar spectrum conversion for photovoltaics using nanoparticles; multiscale modeling of heterojunctions in organic PV; technologies and manufacturing of OPV; life cycle assessment of OPV; new materials and architectures for dye-sensitized solar cells; advances of concentrating $\mathrm{PV}$; modeling doped III/V alloys; polymeric films for lowering the cost of PV, and field performance factors. A panel of acclaimed PV professionals contributed these topics, compiling the state of knowledge for advancing this new generation of PV.

\title{
How to reference
}

In order to correctly reference this scholarly work, feel free to copy and paste the following:

Robert McConnell and Vasilis Fthenakis (2012). Concentrated Photovoltaics, Third Generation Photovoltaics, Dr. Vasilis Fthenakis (Ed.), ISBN: 978-953-51-0304-2, InTech, Available from:

http://www.intechopen.com/books/third-generation-photovoltaics/concentrating-photovoltaics

\section{INTECH}

open science | open minds

\author{
InTech Europe \\ University Campus STeP Ri \\ Slavka Krautzeka 83/A \\ 51000 Rijeka, Croatia \\ Phone: +385 (51) 770447 \\ Fax: +385 (51) 686166 \\ www.intechopen.com
}

\author{
InTech China \\ Unit 405, Office Block, Hotel Equatorial Shanghai \\ No.65, Yan An Road (West), Shanghai, 200040, China \\ 中国上海市延安西路65号上海国际贵都大饭店办公楼 405 单元 \\ Phone: +86-21-62489820 \\ Fax: $+86-21-62489821$
}


(C) 2012 The Author(s). Licensee IntechOpen. This is an open access article distributed under the terms of the Creative Commons Attribution 3.0 License, which permits unrestricted use, distribution, and reproduction in any medium, provided the original work is properly cited. 